
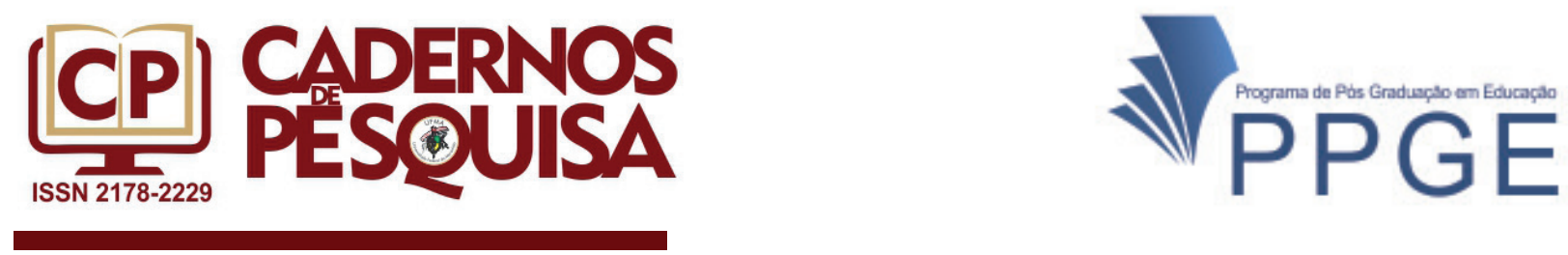

\title{
As recomendações da UNESCO e a educação rural em Sergipe $(1940-1960)$
}

\author{
UNESCO recommendations and the Sergipe rural education \\ (1940-1960)
}

\section{Las recomendaciones de la UNESCO y la educación rural en Sergipe (1940-1960)}

\author{
Maryluze Souza Santos Siqueira ${ }^{1}$ \\ https://orcid.org/0000-0003-2534-120X \\ Raylane Andreza Dias Navarro Barreto 2 \\ https://orcid.org/0000-0002-5602-8534
}

\begin{abstract}
Resumo: O presente artigo traz a análise do papel da UNESCO frente ao processo de modernização da educação no Brasil e a interpretação de como suas recomendações nortearam as mudanças na política educativa para o meio rural em Sergipe nas décadas de 1940 e 1960. Para tanto foram utilizadas como fontes as "Recommandations 1934-1977", documento da UNESCO publicado em 1979, os "Relatórios Manuscritos do Curso de Agricultura (1948)" do professor José Ribeiro Filho, os "Boletins de Inscrição de Clubes Agrícolas das escolas rurais de Sergipe (1949)" e "Relação de escolas rurais e da capital com Clubes Agrícolas em Funcionamento em Sergipe nos anos de 1948 a 1950". Em termos de resultado o que ficou evidenciado foi a supremacia norte-americana, sobretudo no que se refere às politicas de promoção do campo, e, com relação a educação não se pode negar a formação aligeirada dos professores e a pouca eficácia desta formação.

Palavras-chave: Brasil. Formação de professores rurais. Política educativa. Sergipe. Unesco.
\end{abstract}

Abstract: This article brings the analysis of UNESCO function in front of Brazilian education modernization process. Furthermore, the interpretation of how its recommendations had guided the educative politics changes for Sergipe's countryside in the decades of 1940-1960. For this purpose had been in such a way used as sources the "Recommendations (1934-1977)", a UNESCO document published in 1979; the professor Jose Ribeiro Filho "Course of Agriculture Manuscript Reports (1948)"; the "Application Forms of Sergipe's Rural Schools Agricultural Clubs (1949)" and the "Rural Schools with active Agricultural Clubs in Sergipe during the years of 1948-1950". In result terms it was evidenced the North American supremacy, especially concerning to the countryside promotion politics. Regarding to education it cannot deny the hasty professors' qualification and its low effectiveness.

Keywords: Brazil. Educational policy. Rural teachers training. Sergipe. Unesco.

1 Professora da rede estadual de Sergipe e da rede municipal de ensino de Umbaúba/SE. Membro do Grupo de Pesquisa Sociedade, Educação, História e Memória.

E-mail: maryluze@ig.com.br

2 Professora do Centro de Educação e do Programa de pós-graduação em Educação da Universidade Federal de Pernambuco.

E-mail: raylanenavarro@bol.com.br 
Resumen: El presente artículo lleva a cabo un análisis del papel de la UNESCO frente al proceso de modernización de la educación en Brasil y una interpretación de cómo sus recomendaciones guiaron los cambios en la política educativa para el medio rural en Sergipe en las décadas de 1940 a 1960. Al respecto, las fuentes utilizadas fueron las "Recommandations 1934-1977", documento de la UNESCO publicado en 1979; los "Relatórios Manuscritos do Curso de Agricultura" (1948), del profesor José Ribeiro Filho; los "Boletins de Inscrição de Clubes Agrícolas das escolas rurais de Sergipe" (1949) y la "Relação de escolas rurais e da capital com Clubes Agrícolas em Funcionamento em Sergipe nos anos de 1948 a 1950". Lo que el resultado puso en evidencia fue la supremacía norteamericana, sobre todo en lo concerniente a las políticas de promoción del campo; y, respecto de la educación, no es posible negar la superficial formación de los profesores y la escasa eficacia de la misma.

Palabras clave: Brasil. Formación de docentes rurales. Política educativa. Sergipe. Unesco.

\section{INTRODUÇÃO}

[...] as guerras começam nas mentes dos homens, é nas mentes dos homens que devem ser construídas as defesas da paz. (Ato Constitutivo da UNESCO, 1945).

[...] a escola rural, sem objetivar um ensino puramente agrícola, poderia e deveria preparar as crianças do campo para compreenderem a importante, digna, sociável e intelectual vida camponesa, assim como as habilitar do conhecimento científico fundamental que atualmente é necessário para a prática inteligente das vocações rurais. (UNESCO - RECOMENDAÇÃO Nº 8, 1936, tradução nossa).

A partir dessas epígrafes é possível perceber um dos fundamentos constitutivos da UNESCO (Organização das Nações Unidas para a Educação, a Ciência e a Cultura) que é atuar no processo de mudança da mentalidade dos homens com o propósito de alcançar a paz mundial e tudo que a ela esteve e está associado, ou seja, o desenvolvimento e a harmonia entre os povos, a colaboração entre as nações através da educação, da ciência e da cultura, o respeito universal pela justiça, pelo estado de direito e pelos direitos humanos, a expansão e difusão do conhecimento, dentre outros. Nesse sentido, a educação foi pensada como uma das estratégias de atuação e de enfrentamento das questões relacionadas à transformação das sociedades, a partir do desenvolvimento e da modernização, especialmente das áreas consideradas atrasadas, como o meio rural brasileiro que passava a expor demandas de toda ordem, a exemplo da expansão da educação através de escolas e da formação de professores para nelas atuarem.

A escola rural, a partir dessa lógica, foi pensada enquanto um espaço capaz de oferecer ao rurícola saberes científicos necessários para que ele pudesse valorizar a vida no campo, modificar as condições de vida no meio rural, assim como aprimorar/modernizar o trabalho e a produção agrícola. Para tanto, a formação do professor rural seria um elemento fundamental, pois ele é quem estaria diretamente envolvido com as populações rurais e precisaria adquirir tais conhecimentos, tendo em vista que naquele contexto do final dos anos de 1930 e 1940 os professores eram predominantemente leigos. 
Diante de tais prerrogativas, neste artigo, tivemos o objetivo de analisar o papel da UNESCO frente ao processo de modernização da educação e interpretar como suas recomendações nortearam as mudanças na política educativa para o meio rural em Sergipe nas décadas de 1940 a 1960. Espera-se, com isso, esclarecer a relação entre o prescrito e o vivido, ou, em outras palavras, entre as Recomendações da UNESCO e as políticas de educação rural no contexto sergipano e o que dessa relação decorre no sentido de expandir, modernizar o campo e formar professores primários rurais.

Tal propósito se soma aos esforços de escrita de tese doutoral que tem por objetivo compreender como se configurou o campo de formação e de atuação do professor primário rural em Sergipe no recorte temporal de 1940 a 1963. Nesse sentido, para este artigo, duas foram as questões de pesquisa que nos motivaram: - Quais recomendações para a educação rural mundial foram propostas pela UNESCO? Como as Recomendações da UNESCO foram atendidas pelo governo sergipano no processo de expansão das escolas primárias e para a formação de professores rurais? Para buscar atender aos questionamentos foram necessárias as pesquisas bibliográfica e documental e nesse sentido, para além da bibliografia voltada para a temática, as principais fontes utilizadas foram: "Recommandations 1934-1977", documento da UNESCO publicado em 1979, os "Relatórios Manuscritos do Curso de Agricultura (1948)" do professor José Ribeiro Filho, os "Boletins de Inscrição de Clubes Agrícolas das escolas rurais de Sergipe (1949)" e "Relação de escolas rurais e da capital com Clubes Agrícolas em Funcionamento em Sergipe nos anos de 1948 a 1950".

\section{A UNESCO E A EDUCAÇÃO NO CONTEXTO PÓS II GUERRA MUNDIAL}

Após o fim da Segunda Guerra Mundial (1939-1945), lideranças mundiais ligadas à $\mathrm{ONU}^{3}$ (Organização das Nações Unidas) imbuídas do propósito de construção de uma nova ordem econômica criam Organizações intergovernamentais, entre as quais a UNESCO. A criação, especificamente desta organização se deu em 1945, na $19^{\text {a }}$ Conferência de Ministros Aliados da Educação ${ }^{4}$ (CMAE), em Londres, onde diversos interlocutores dos Estados-Membros da ONU debruçaram-se sobre os problemas relativos às áreas educacional e cultural em todo o mundo. Ao longo da sua existência, seus membros buscam pensar e

3 Organização das Nações Unidas (ONU) é uma organização intergovernamental criada para promover a cooperação internacional. Em substituição à Liga das Nações foi estabelecida em 24 de outubro de 1945, após o término da Segunda Guerra Mundial. A sua sede está localizada em Manhattan, Nova York (EUA). Os seus objetivos incluem manter a segurança e a paz mundial, promover os direitos humanos, auxiliar no desenvolvimento econômico e no progresso social, proteger o meio ambiente e prover ajuda humanitária em casos de fome, desastres naturais e conflitos armados.

4 A Conferência de Ministros Aliados da Educação (CMAE) nasceu na Inglaterra em 1942, durante a II 
criar recomendações, acordos e projetos de intervenção com vistas ao desenvolvimento das nações (EVANGELISTA, 1999).

Como já anunciado, um dos principais objetivos da UNESCO é a defesa da paz mundial, da segurança e da liberdade entre os povos. Para tanto se tornou imprescindível, desde a sua criação, a cooperação entre as nações no campo da educação, da ciência e da cultura. Mesmo que naquele contexto esta fosse uma ação complexa, tendo em vista o processo de reconstrução e reorganização social e econômica dos países recém-saídos da II Guerra, assim como, os conflitos entre os países dos dois blocos, o capitalista liderado pelos Estados Unidos da América (EUA) e o comunista, sob o comando da União Soviética (URSS).

Nesse sentido, a UNESCO foi incumbido o papel de intermediação entre os EstadosMembros e o de negociar seus objetivos com os Estados imperiais e com as resistências dos povos colonizados, que em meio às contínuas guerras locais, contavam com as contradições do capitalismo e a defesa da democracia, da liberdade e da paz, pois naquele contexto também viviam a chamada Guerra Fria, designação atribuída ao período histórico de disputas estratégicas e conflitos indiretos entre os Estados Unidos e a União Soviética, que ocorrera entre o final da Segunda Guerra Mundial (1945) e a extinção da União Soviética (1991), envolvendo também as respectivas zonas de influência.

No referido período, a ONU defendia que a paz e a harmonia poderiam ser conquistadas por meio do progresso da humanidade em direção ao universal, sendo este o objetivo maior, embora não isento de contradições e de ambiguidades, que deveriam ser mediadas pela UNESCO. Essa era de fato uma tarefa complexa para uma organização intergovernamental, posto que naquela circunstância estivesse se reescrevendo o mapa do mundo e se processando uma nova divisão do mercado mundial. Segundo Evangelista (1999, p.65), vivia-se, portanto, um estado "[...] de acomodações, disputas, afirmação e reconstrução dos espaços nacionais e culturais. Momento, ainda, de surgimento do antagonismo entre modos diversos de organização da vida social, e de busca dos possíveis no confronto de civilizações diversas [...]".

Assim, foi no mundo dividido pela Guerra Fria que a UNESCO se constituiu como entidade transnacional e assumiu a liderança no processo de negociações para a paz. Contudo, é preciso destacar que ainda que sua sede estivesse na França, ela teve nos Estados Unidos um dos grandes interlocutores desse processo, sendo este país um defensor da li-

Guerra Mundial, quando representantes dos países invadidos pela Alemanha encontravam-se exilados em Londres e por meio desse fórum discutiram possíveis iniciativas para a reconstrução dos sistemas educacionais dos países que estavam em conflito. 
berdade, entendida enquanto prerrogativa exclusiva do modo capitalista de organização da vida social. Há que se considerar, também, que naquela conjuntura, a posição de liderança assumida pelos EUA justificava-se pelo fato de estarem numa condição privilegiada frente aos aliados europeus e asiáticos, pois a II grande Guerra não abalou sua economia que foi fortalecida pelo aumento da produtividade, e, tão pouco o seu território, que por estar distante dos conflitos, manteve sua integridade.

Com o objetivo de combater o comunismo (URSS) e expandir o capitalismo pelo mundo, assim como promover a paz e o desenvolvimento, os EUA junto aos países aliados atuaram por meio dos organismos internacionais criados a partir do final da referida guerra, em 1945. Nesse sentido, para além da ONU, contaram com o Banco Mundial' ${ }^{5}$ (BM), o Fundo Monetário Internacional ${ }^{6}$ (FMI), a Organização Mundial do Comércio ${ }^{7}$ (OMC), Organização do Tratado do Atlântico Norte ${ }^{8}$ (OTAN), a Comissão Econômica para a América Latina ${ }^{9}$ (CEPAL), a Organização para Cooperação e Desenvolvimento Econômico ${ }^{10}$ (OCDE), a Organização dos Estados Americanos ${ }^{11}$ (OEA) e a própria UNESCO, para além de contarem

5 A missão inicial do Banco Mundial (1945) foi de financiar a reconstrução dos países devastados pela Segunda Guerra Mundial. Com o tempo a sua missão evoluiu para financiamento o desenvolvimento dos países mais pobres e de seu auxílio financeiro.

6 O Fundo Monetário Internacional (FMI) é um organismo intergovernamental também criado em 1945 pela ONU, cujos objetivos são promover políticas cambiais sustentáveis a nível mundial, facilitar o comércio internacional e reduzir, a nível mundial, a pobreza.

7 As origens da OMC remontam à assinatura do Acordo Geral sobre Tarifas e Comércio (GATT), em 1947, mecanismo que foi responsável, entre os anos de 1948 a 1994, pela criação e gerenciamento das regras do sistema multilateral de comércio. No âmbito do GATT, foram realizadas oito rodadas de negociações comerciais, que tiveram por objetivo promover a progressiva redução de tarifas e outras barreiras ao comércio. A oitava rodada, conhecida como Rodada Uruguai, culminou com a criação de OMC e de um novo conjunto de acordos multilaterais que formaram o corpo normativo da nova Organização.

8 A OTAN é uma organização militar, composta por 29 países, que se formou no ano de 1949. Ela foi constituída no contexto histórico da Guerra Fria, como forma de fazer frente à organização militar socialista denominada Pacto de Varsóvia, liderada pela ex-União Soviética e integrada por países do leste europeu.

9 A Comissão Econômica para a América Latina (CEPAL) foi estabelecida em 1948. É uma das comissões regionais das Nações Unidas e foi fundada para contribuir para o desenvolvimento econômico da América Latina, coordenar as ações encaminhadas à sua promoção e reforçar as relações econômicas dos países entre si e com as outras nações do mundo. Posteriormente, seu trabalho foi ampliado aos países do Caribe e se incorporou o objetivo de promover o desenvolvimento social.

10 A OCDE foi criada em 1960 e conta hoje com aproximadamente 30 membros da Europa, Américas, Ásia e Oceania. Além disso, mantém relações com mais de 70 países não-membros. Atua principalmente na área social e econômica, abordando temas como macroeconomia, comércio, desenvolvimento, educação, ciência e inovação. Entre os objetivos da OCDE estão fomentar a boa governança estatal e empresarial, o desenvolvimento social e o crescimento econômico por meio de cooperação institucional e política, assim como a utilização de mecanismos de monitoramento.

11 A OEA foi fundada em 30 de abril de 1948, constituindo-se como um dos organismos regionais mais antigos do mundo, sendo fundada três anos após a criação da ONU. Com 21 países signatários, entre eles o Brasil, reunidos em Bogotá, Colômbia, assinaram a Carta da Organização dos Estados Americanos, 
com o Pacto de Varsóvia ${ }^{12}$, dentre outros, que passaram a oferecer assistência e cooperação técnica às nações.

No que se refere especificamente a UNESCO, o seu Ato Constitutivo determinou como suas atribuições:

a) favorecer a compreensão mútua das nações: [...] emprestando seu concurso aos órgãos de informação das massas, visando a facilitar a livre circulação das idéias [sic] pela palavra e pela imagem; b) imprimir um impulso vigoroso à educação popular e à difusão da cultura, através da cooperação entre as nações, sugerindo métodos de educação para preparar as crianças do mundo inteiro para as responsabilidades do homem livre; c) ajudar a manutenção, o avanço e a difusão do saber [...] facilitando [...] o acesso de todos os povos ao que cada um deles publica (apud EVANGELISTA, 1999, p.16).

Com o foco no atendimento desses objetivos a educação foi tomada como campo de atuação necessária ao desenvolvimento, e, para a UNESCO adentrar nos países foi preciso estabelecer em suas ações um movimento de mobilização e modernização que integrasse a educação aos outros diversos setores da sociedade mundial, como economia, política, tecnologia e cultura. Para tanto, foram propostos e aprovados já na $1^{a}$ Conferência Geral da UNESCO, em 1946, projetos de educação para serem realizados nos países destruídos pela II Guerra, bem como naqueles que precisavam entrar nos trilhos da economia e do desenvolvimento internacionais, como os países da América Latina. Vale ressaltar que anteriormente já tinham acontecido outras Conferências Internacionais de Educação sobre a anuência da ONU e tinham sido propostas "Recomendações" para todas as áreas da educação mundial, até mesmo para as áreas rurais. Foi por isso, inclusive, que a educação passou a ser associada ao desenvolvimento técnico promovido pela ciência e tecnologia.

Predominava então a noção de uma educação que, se aliada aos progressos técnicos da civilização, seria responsável por formar o cidadão capaz de responder às novas

onde a organização definia-se como um organismo regional dentro das Nações Unidas. Os países-membros se comprometiam a defender os interesses do continente americano, buscando soluções pacíficas para o desenvolvimento econômico, social e cultural.

12 O Pacto de Varsóvia foi uma aliança militar formada em 14 de maio de 1955 pelos países socialistas do Leste Europeu e pela União Soviética, estabelecendo um compromisso de ajuda mútua em caso de agressões militares e legalizando na prática a presença de milhões de militares soviéticos nos países do leste europeu desde 1945. O organismo militar foi alegadamente instituído em contraponto à OTAN (Organização do Tratado do Atlântico Norte), organização internacional que uniu as democracias da Europa Ocidental e os Estados Unidos para a prevenção e defesa dos países membros contra eventuais ataques vindos do Leste Europeu. As mudanças no cenário geopolítico da Europa Oriental no final da década de 1980, com a queda dos governos socialistas, o fim do Muro de Berlim, a crise na União Soviética levaram à extinção do Pacto em 31 de março de 1991. O fim do Pacto de Varsóvia representou, também, o fim da Guerra Fria. 
exigências da sociedade em processo de modernização. Nesse sentido, com o respaldo financeiro do Banco Mundial, também interessado nesse progresso, a UNESCO passou a atuar com serviços de assessoria técnica na Europa, Ásia, África e na América Latina, priorizando projetos de infraestrutura material e as reformas das estruturas educacionais, a fim de sintonizá-las quantitativa e qualitativamente com o desenvolvimento econômico capitalista (EVANGELISTA, 1999). Dessa forma, acreditava-se no papel da educação como promotora do desenvolvimento e da transformação da sociedade com o foco na liberdade, democracia e modernização. Nesse sentido:

A palavra 'modernização' foi introduzida como termo técnico, nos anos 1950, na tentativa de conceituar um conjunto de processos cumulativos e de reforço mútuo à formação de capital e mobilização de recursos; ao desenvolvimento das forças produtivas e ao aumento da produtividade do trabalho; ao estabelecimento do poder político centralizado e à formação de identidades nacionais; à expansão dos direitos de participação política, das formas urbanas de vida e da escola formal; à secularização de valores e de normas, dentre outros (CARVALHO, 2012, p. 2).

Nessa perspectiva, a modernização estava associada aos valores e projetos voltados para o melhoramento econômico e social das sociedades, a partir do acúmulo de capitais (incluindo o cultural) e do aumento da produção e democratização de bens e serviços. Para tanto, havia a crença de que a aquisição de novas técnicas, de processos racionais e planificados, bem como das descobertas científicas dar-se-ia por meio da atuação da escola e, a partir de então, seria possível estabelecer mecanismos de desenvolvimento e de modernização das sociedades. (EVANGELISTA, 1999). É importante ainda ressaltar que essa perspectiva também estava direcionada para a educação rural, tendo em vista que a maior parte dos países tinha na terra sua maior fonte de renda e, portanto, a sua modernização promoveria o progresso.

Diante dessas circunstâncias, foi que os Estados Unidos, com a intenção de ratificar suas ações que disseminava cada vez mais o capitalismo com o propósito de desenvolvimento e modernização no mundo, estabeleceram e lideraram os acordos de cooperação, financiamento e pesquisas nas áreas política, social, educacional e cultural em diversos países da Europa e da América Latina. Nesse contexto, segundo Daniel (2009), as ciências sociais exerceram um papel fundamental para a análise dos problemas sociais e no direcionamento do planejamento econômico e do desenvolvimento social dos países latino-americanos, a partir da produção de inquéritos, diagnósticos e planos de trabalho. Da mesma forma, as estatísticas educacionais apresentavam os déficits, principalmente no número de alfabetizados e de acesso à escola, fatos que demandavam medidas governamentais para sua reversão.

No caso do Brasil, especificamente em 1933, as estatísticas apresentavam índices alarmantes referentes à baixa escolarização, especialmente na zona rural, onde se 
concentrava a população. A maioria dos brasileiros estava situada na zona rural, sendo que a população média geral do Brasil era de 31.430.230 habitantes, e desta, 27.295.532 correspondiam à população média da zona rural, ou seja, $77,04 \%$, enquanto que apenas 8.134.698 correspondiam à população média da zona urbana, o que equivalia a $22.96 \%$. (ÁVILA, 2013). No que se refere ao analfabetismo, os índices eram bastante elevados entre os jovens e adultos. De acordo com o IBGE/Censo Demográfico, em 1940, do total de 23.648.000 brasileiros entre 15 anos ou mais, o número de analfabetismo era de 13.269.000, correspondendo a 56,1\%. E em 1950 os dados do IBGE apontavam que a população ainda era majoritariamente rural e mais de $70 \%$ da população adulta da zona rural não dominava sequer os rudimentos da leitura e escrita. Ainda em 1950, por sua vez, do total de 30.188 .000 habitantes com 15 anos ou mais, 15.272 .000 , ou seja, 50,6\% eram analfabetos, percentual que caiu significativamente em 1960, quando a referida população era de 40.233.000, e destes 15.964.000, isto é, 39,7\% continuavam analfabetos. Apesar da redução dos índices, em termos absolutos, o número de habitantes sem instrução comprometia o desenvolvimento do país, como atestavam os especialistas e os órgãos do governo na época. (SILVA, 2016).

\section{O PRESCRITO PELA UNESCO}

No estado de Sergipe a situação do meio rural não era diferente. Segundo recenseamento de 1950, Sergipe contava com 644.361 habitantes, dos quais somente 33,63\% sabiam ler e escrever. Da população de dez anos e acima desta faixa etária (441.478 habitantes) que não sabiam ler e escrever, 79,49\% estavam na zona rural e dedicavam-se às atividades agropecuárias (NUNES MENDONÇA, 1958). Como se pode notar o analfabetismo na zona rural era elevado e este fato fez com que as autoridades governamentais precisassem de projetos para expandir o ensino primário no país e foi, justamente, nessa conjuntura que contou com a colaboração internacional dos EUA e da UNESCO.

Para além da prevalência das atividades econômicas ligadas à terra, desde os anos de 1930, no Brasil já vinha ocorrendo um processo de desenvolvimento industrial realizado sob as condições impostas pela mundialização de um capital monopolista. Tal processo também gerou inúmeras demandas, inclusive a promoção de mudanças na educação nacional. Contudo, somente a partir do final do Estado Novo (1937-1945) quando estava à frente do Ministério da Educação, Gustavo Capanema (1934 e 1945) é que elas foram aprofundadas. Como exemplo, tivemos as Leis Orgânicas do Ensino publicadas a partir de 1942, que estruturou o ensino industrial, reformou o ensino comercial e criou o Serviço Nacional de Aprendizagem Industrial - SENAI. A partir de 1946, já no fim do Estado Novo e 
durante o Governo Provisório e a partir da Lei Orgânica do Ensino Primário foi organizado esse nível de ensino com diretrizes gerais, bem como foi organizado o ensino primário supletivo, com duração de dois anos, destinado a adolescentes a partir dos 13 anos e adultos; como também o ensino normal, o ensino agrícola e o Serviço Nacional de Aprendizagem Comercial - SENAC. (ROMANELLI, 1978).

Durante o período de 1946 a 1964 foram realizadas diversas ações no âmbito educacional, as quais favoreceram a garantia de direitos, assim como permitiram a criação de diversos espaços institucionais voltados para a reorganização do sistema educativo, tais como:

O direito constitucional à educação; foi elaborada e aprovada a primeira lei de diretrizes e bases da educação nacional; elaborou-se um complexo plano estratégico de desenvolvimento educacional, científico, tecnológico e cultural, inclusive redirecionando o papel de instituições educacionais, como o INEP, ou criando novas instituições voltadas ao desenvolvimento científico e à formação de quadros para o ensino superior, como a Coordenação de Aperfeiçoamento do Pessoal do Ensino Superior (CAPES); a criação do Conselho Federal de Educação (em 1961); a realização de campanhas e movimentos voltados à alfabetização de adultos, à educação e à cultura popular. (MARCíLIO, 2005, p.151).

Como se mostrou anteriormente, apesar dessas estruturações na organização da educação brasileira, os resultados ainda se apresentavam de forma negativa nos anos de 1950. Nesse sentido, nos novos encaminhamentos no campo da educação do país era notória a incorporação das diretrizes estabelecidas pelos organismos internacionais, na medida em que estes defendiam a racionalização do sistema educacional dos países periféricos e com isso atribuíam à educação a capacidade de desenvolver e modernizar esses países.

Nesse contexto, o Brasil adotava como plano econômico o modelo de substituição de importações, resultado de uma política econômica nacional- desenvolvimentista com o objetivo de desenvolver o setor industrial e resolver os problemas de dependência de capitais externos, que impediam o desenvolvimento da nação. Nesse sentido, foram realizados grandes investimentos na exploração de minerais, na metalurgia, na siderurgia e em setores tecnologicamente mais sofisticados. Esse período da história brasileira é usualmente chamado de desenvolvimentismo ou nacional desenvolvimentismo, que prevaleceu no governo de Getúlio Vargas (1930-1945) e em especial na gestão de Juscelino Kubitschek (1956-1961), fazendo o Brasil abraçar definitivamente a industrialização. (LOMBARDI, 2014).

Como previsto, esse processo foi balizado pela Comissão Econômica para a América Latina e Caribe (CEPAL), que, por meio de seus agentes intelectuais, propagaram a "teoria do desenvolvimento", propondo que a industrialização latino-americana seria o caminho para a superação do atraso e do subdesenvolvimento. A CEPAL defendia, também, que 
somente a industrialização não era suficiente para resolver os problemas de desigualdades sociais nos países latinos, de modo que, devia-se adotar uma estratégia de transformação produtiva com equidade social que possibilitasse um crescimento econômico sustentável e que fosse articulado a uma melhor distribuição de renda, e, para tanto, seria necessário o apoio dos países desenvolvidos e o capital financeiro internacional (LOMBARDI, 2014).

A forma de conceber a passagem do atraso para a modernidade permitiu a propagação do ideário desenvolvimentista, ratificado por Xavier (2012, p. 213), quando afirma ser ele "[...] um pensamento que proclamou o princípio de que o crescimento da economia dependia da expansão industrial, do recurso do capital estrangeiro, do investimento no planejamento setorial e na racionalidade da administração pública”. Nesse sentido, a educação passou a ser pensada e organizada no Brasil como parte de um "[...] sistema civilizacional fortemente relacionado com a ordem econômica capitalista” (DAROS, 2012, p.188).

Daros (2012) sintetiza a situação ao afirmar que a criação das organizações internacionais de natureza supranacional como a UNESCO deu um forte impulso à internacionalização das problemáticas educacionais. As conferências, missões e assistência técnica e financeira oferecidas a inúmeros países, entre os quais o Brasil, fazia parte do esforço para estabelecer uma racionalidade científica que permitisse "[...] criar vastas redes de contatos, de financiamentos e de permuta de informações e conhecimentos entre autoridades político-administrativas de âmbito nacional, actores sociais experts e investigadores universitários" (DAROS, 2012, p. 189).

A perspectiva de desenvolvimento então proposta, como já anunciado, considerava que a educação deveria assumir um papel prioritário, devendo adotar a concepção de planejamento e racionalização em suas políticas, o que levou diversos intelectuais com trânsito nos Estados Unidos e em organismos internacionais como a UNESCO e em entidades nacionais como o Instituto Nacional de Estudos Pedagógicos ${ }^{13}$ (INEP), a terem uma importância nesse processo e assim os exemplos de Lourenço Filho, Anísio Teixeira, João Roberto Moreira e Murilo Braga, dentre outros, que atuaram no período do governo do presidente Gaspar Dutra (1946-1951) são decisivos, uma vez que eles promoveram e lideraram reformas e projetos educacionais implementados no período, inclusive na educa-

13 "O INEP foi criado em janeiro de 1937, por iniciativa de Gustavo Capanema, à época Ministro de Educação e Saúde (MES), sob a denominação inicial de Instituto Nacional de Pedagogia. Apenas em 1938, no entanto, ele começa a ter existência real, sob a liderança do educador Lourenço Filho e já com a denominação de Instituto Nacional de Estudos Pedagógicos. Múltiplos objetivos foram atribuídos ao INEP através do Decreto-Lei $n^{\circ} 580$, de 30 de julho de 1938: organizar a documentação relativa à história e ao estudo atual das doutrinas e técnicas pedagógicas, bem como das diferentes espécies de instituições educativas; manter o intercâmbio em matéria de pedagogia com as instituições educacionais do país e do estrangeiro; promover inquéritos e pesquisas sobre todos os problemas atinentes 
ção rural, continuando a atuação, após essas, em diversos espaços da esfera educacional. (MARCÍLIO, 2005).

No bojo de todas as preocupações sociais e educacionais, à educação rural foi dado certo protagonismo na medida em que passou a ser um espaço de interesse dos organismos internacionais, inclusive levando os EUA a firmar com o governo brasileiro acordos de cooperação técnica específicos, com o objetivo de modernização desse campo. Dentre os acordos estabelecidos na perspectiva de promoverem a educação rural no Brasil, Mendonça destaca:

1) Acordo entre o Ministério da Agricultura e Divisão de Educação do Institute of Inter-American Affairs de 1945, que originou a própria CBAR; ${ }^{14}$ 2) acordo entre o Instituto Nacional de Estudos Pedagógicos do MES (INEP ) e o governo americano, para implementação do curso 'Escola para o Brasil Rural' ministrado no Distrito Federal por docentes norte-americanos em 1949; 3) acordo que originou a Campanha de Educação de Adolescentes e Adultos (CEAA), em vigor entre 1947 e 1963, tendo por lastro operacional uma rede de missões rurais incumbidas de percorrer o interior alfabetizando e difundindo a noção de 'desenvolvimento comunitário'; 4) acordo' ${ }^{15}$ originalmente firmado entre governo norte-americano e o Ministério da Educação em 1950, com vistas à criação da Campanha Nacional de Educação Rural (CNER), destinada a erradicar o analfabetismo e preparar professores rurais especializados, acordo este inconcluso ante a recusa do Congresso Nacional em aprová-lo; [...] (MENDONÇA, 2010, p. 94).

Assim, a partir das propostas estabelecidas nesses acordos e nas ações que eles desencadearam no Brasil não é possível entender os projetos desenvolvidos em prol da modernização da educação rural em nenhum estado do Brasil sem concebê-los como frutos de tais acordos e como parte de um projeto maior de desenvolvimento mundial e de modernização da educação, defendido pelos organismos internacionais naquele contexto que, por meio de Recomendações, orientavam os países a modernizarem suas políticas educacionais.

às instituições educacionais do país e do estrangeiro; promover investigação no terreno da psicologia aplicada à educação, bem como relativamente aos problemas de orientação e seleção profissional; prestar assistência técnica aos serviços estaduais, municipais e particulares de educação, ministrando-lhes, mediante consulta ou independentemente desta, esclarecimentos e soluções sobre os problemas pedagógicos; divulgar, pelos diferentes processos de difusão, os conhecimentos relativos à teoria e à prática pedagógica." (MENÇONÇA, 2005, p. 4-5).

14 Comissão Brasileiro-Americana de Educação das Populações Rurais.

15 Esse acordo previa a criação da Comissão Americano-Brasileira de Educação Rural (CABER) que atuaria como órgão consultivo do programa de educação rural do Ministério da Educação. Porém, esse acordo não se concretizou porque o Congresso Brasileiro não aprovou os recursos previstos para a execução de suas ações. Os valores previstos financiariam programas de orientação e treinamento de professores, administradores, supervisores e técnicos de ensino rural, bem como a aquisição de equipamentos, preparação de material de ensino e auxílios didáticos, além da prestação de serviços biblioteconômicos. Como a aprovação da CABER foi recusada, os dirigentes do MES implantaram com recursos próprios uma iniciativa equivalente, a Campanha Nacional de Ensino Rural (CNER) em 1952 (MENDONÇA, 2010). 


\section{RECOMENDAÇÕES DA UNESCO E A EDUCAÇÃO RURAL EM SERGIPE}

Como já sinalizado a UNESCO traçou orientações para os diversos setores da educação mundial, dentre as ações desencadeadas a partir das Conferências Internacionais de Educação, aponta-se que foram estabelecidas 71 (setenta e uma) Recomendações no período de 1934 a 1977, as quais se destacam, neste estudo, aquelas relacionadas à organização da educação rural, intercâmbio internacional de professores, formação de professores primários e instalações para educação em áreas rurais.

Nesse sentido, a "Recomendação n 8", refere-se à "Organização da Educação Rural" e foi apresentada, em 1936, no International Bureau of Education ${ }^{16}$ (IBE) durante a Conferência Internacional de Educação Pública. Nela encontram-se várias orientações às quais os Ministérios de Educação Pública deveriam adotar em seus países. Dentre elas está a que assegura que os alunos da zona rural, tenham o mesmo nível de qualidade de ensino que os da zona urbana, o que incluía concluírem seus estudos e terem acesso ao ensino médio, ou seja, que não estudassem apenas o ensino primário, prática bastante comum nos países periféricos.

A partir do conhecimento de que em várias partes do mundo os alunos da zona rural enfrentavam dificuldades dadas às condições desfavoráveis para estudarem, na "Recomendação" a Unesco definia que os professores procurassem, na medida do possível, remediar as situações encontradas para manter o padrão existente nas escolas urbanas, inclusive adaptando os programas de ensino das escolas rurais às condições locais e considerando os seus "centros de interesse" 17 .

1) Deverá ser um princípio aceito que a educação dada às crianças nas escolas rurais não deve ser de forma alguma inferior àquela dada às crianças nas escolas urbanas, isso as permitirá de passarem para as escolas secundárias;

16 International Bureau of Education (IBE) foi criado em 1925 e inicialmente era um órgão privado. Em 1929 passou a vincular-se ao governo para que pudesse continuar atuando no campo da educação, pois não contava com recursos financeiros suficientes para atuar sozinho. As Recomendações são resultados das Conferências Internacionais sobre Educação Pública, ocorridas em Genebra, anualmente, de 1934 até o início da Segunda Guerra Mundial em 1939, e de 1947 a 1977. O trabalho do IBE continuou durante os anos de guerra, mas não foi possível chamar outra Internacional Conferência sobre Educação Pública até março de 1946. A partir de 1947, essas conferências foram convocadas conjuntamente pela ONU e UNESCO.

17 Centros de Interesse são resultados do método educacional desenvolvido pelo educador belga Ovide Decroly (1871-1932), que partia da ideia da globalização do ensino para romper com a rigidez dos programas escolares. Sua finalidade seria preparar o aluno para a vida e para isso a escola deveria se situar num ambiente que tornasse possível o estudante observar os fenômenos da natureza e as manifestações de todos os seres vivos. Foram utilizados como metodologia na Escola Ativa e Escola Nova no Brasil a partir da década de 1930. 
2) Para esse fim, e para assegurar maior justiça no campo da educação, deverá ser realizado um esforço para remediar, na medida do possível, quaisquer condições desfavoráveis que ainda possam existir nas escolas rurais;

3) Deverá ser assegurado em todas as escolas o mesmo nível de instrução, seja na cidade ou no campo, sendo naturalmente necessário que os professores adaptem seus currículos às condições locais e, em particular, atraiam seus 'centros de interesse' do ambiente em que vivem seus alunos (UNESCO, 1979, p.18, tradução nossa).

Como pode ser percebido, para além dos "centros de interesse", também solicitava que o professor utilizasse outros princípios da Pedagogia da Escola Nova, pois entendia que o currículo das escolas primárias deveria ter influência sobre as condições de vida no país. Nesse sentido, os professores rurais utilizariam os conhecimentos oferecidos pelo meio ambiente; fariam o estudo da realidade próxima ao estudante e assim desenvolveriam, em seus alunos, a partir das potencialidades, um gosto pela vida rural. A referida Recomendação, em seus incisos 6 e 7, também considerava:

6) O currículo geral das escolas elementares deverá ter uma influência definitiva sobre as condições de vida no país;

7) Os professores rurais deverão utilizar as instalações peculiares para o ensino oferecido pelo seu ambiente, de modo a dar um caráter concreto e vivo às suas aulas e, assim, desenvolver nos seus alunos o gosto pela vida rural (UNESCO, 1979, p.18, tradução nossa).

Nessa perspectiva, outra preocupação percebida na Recomendação nº 8 foi em relação às escolas de sala multisseriada com apenas um professor. Contra essa prática, havia uma defesa das escolas centrais e consolidadas que deveriam ser almejadas como princípio modernizador, mesmo que na prática sua substituição fosse paulatina. Nesse sentido:

9) A fim de habilitar as escolas rurais de uma educação completa, o número máximo de alunos a serem admitidos em qualquer escola de professor único deve ser estritamente limitado;

10) Um esforço final deverá ser feito para reduzir o número de escolas de professores únicos, tanto quanto possível, através do fornecimento de escolas centrais ou consolidadas; e que, mesmo que essas escolas sejam retidas para os alunos mais jovens, as classes centrais devem, de qualquer forma, ser estabelecidas para os meninos e meninas mais velhos e, para isso, devem ser tomadas as providências necessárias para transporte e alimentação (UNESCO 1979, p. 18-19, tradução nossa).

No Brasil, as escolas com tal modelo formativo eram chamadas de "escolas isoladas" e continuaram existindo, mesmo após serem construídas as escolas primárias rurais e os Grupos Escolares no campo e na cidade. Em Sergipe, especificamente, mesmo o plano de expansão das escolas rurais, executado no final da década de 1940, se deu a partir de 
um modelo de escola tipicamente rural, ratificado tanto na arquitetura, contendo uma sala para moradia do professor anexa à sala de aula, quanto na inclusão de atividades agrícolas nas práticas escolares, para além dos cursos de formação específica do professor (SILVA, 2016).

Esse projeto foi implantado, em Sergipe, por Acrísio Cruz que era o diretor do Departamento de Educação e atuou com a anuência do INEP. Ao considerar o problema das construções escolares no Brasil, Acrísio Cruz considerou, em entrevista concedida a Luiz Antônio Barreto (2006) que desde os primórdios da nacionalização, o Brasil enfrentava um déficit escolar e destacou que em 1949 estava fora da escola dois milhões e quinhentas mil (2.500.000) crianças de 7 a 11 anos, sem falar das zonas interioranas que, pelas dificuldades de apuração, não tinha como ele afirmar de modo preciso.

Outro ponto abordado pelo diretor foi os tipos inadequados de prédio onde funcionavam as escolas ou salas de aula, que causavam "[...] vários inconvenientes, entre outros a utilização de casas impróprias, muitas delas sem higiene, mal localizadas, piso ordinário, de terra batida, muitos outros". (CRUZ, 1966 apud BARRETO, 2006, p.96). Diante dessa situação, ele defendia que era preciso o Brasil atender em primeiro lugar "[...] as populações rurais como meio dinamizador do engrandecimento das energias produtivas da comunidade" (BARRETO, 2006). Pensado a época, Cruz destacou:

A situação do mundo presente e a realidade brasileira já não permitem digressões teóricas; o que importa é agir, com a maior segurança possível, visando sempre ao bem coletivo. Daí a simplicidade do plano do INEP: construir escolas onde não existam ou onde sejam precárias. (CRUZ apud BARRETO, 2006, p.95).

Nesse sentido, diante das afirmações e defesas de Acrísio Cruz referentes à educação é possível perceber que seu pensamento estava alinhado ao que vinha sendo defendido pelas políticas do INEP tendo à frente seu diretor Murilo Braga, entretanto, a falta de professores formados para atuarem na área e a precária estrutura predial de boa parte das escolas foram entraves para a qualidade do plano.

Com vistas a sanar tais dificuldades a Recomendação $n^{\circ} 8$ defendia que os professores das escolas rurais não deveriam ter um estatuto inferior ao das escolas urbanas, como diferença salarial e exigência de formação. Para tanto era definido que fossem ofertados cursos de curta duração em instrução agrícola ou doméstica para os professores que quisessem continuar nas áreas rurais; que eles deveriam ter benefícios especiais para compensar os inconvenientes de viver longe das cidades e que fossem estimulados a permanecerem nas áreas rurais. Já os incisos 12, 13 e 14 assim se configuraram: 
12) Os professores das escolas rurais não deverão ter um status inferior ao dos professores nas escolas da cidade; [...]

13) Deverá ser organizado cursos de curta duração em instrução agrícola ou doméstica para homens e mulheres professores que desejam especializar-se em trabalhos de pós-escola ou de continuação em áreas rurais;

14) Benefícios especiais deverão ser concedidos aos professores das escolas rurais para compensá-los pelos inconvenientes e desvantagens de viver longe das cidades, encorajando-os em alguma medida a permanecer nas áreas rurais (UNESCO, 1979, p. 19, tradução nossa).

O governo de Sergipe, buscando atender a tais sugestões, sistematizou as iniciativas quanto à formação de professores a partir das orientações do Decreto-Lei n. 4.958, de 14 de novembro de 1942, que criou o Fundo Nacional de Ensino Primário com o objetivo de ampliar e melhorar o sistema escolar primário de todo país. Nesse sentido, em 1944 foi elaborado um plano para expansão da educação rural para o Brasil a partir da utilização desse Fundo, mas foi a partir de 1946 que o INEP assumiu e intensificou as construções de escolas e formação do professor para as zonas rurais. Assim, em nível nacional, as diretrizes para a formação de professores estava regulamentada pela Lei Orgânica do Ensino Normal (1946) o que possibilitou que fossem criados os Cursos Normais Regionais ${ }^{18}$ e também as Escolas Normais Rurais, inclusive foram ofertados tanto bolsas de estudo, quanto cursos de curta duração para professores rurais.

Nesse sentido, foi por meio da Lei $n^{\circ} 212$, de 29 de novembro de 1949, que o governo de Sergipe, como reflexo da perspectiva ruralista da educação em vigor, e com o objetivo de atender as exigências de preparação do professor primário rural, assim determinou:

Art. $1^{\circ}$ - Ficam criadas duas (2) Escolas Normais Rurais, com sede nas cidades de Lagarto e Itabaiana, respectivamente.

Parágrafo Único - Cada Escola Normal Rural manterá um curso de Ginásio e um de Formação de Professores.

Art. $2^{\circ}-\mathrm{O}$ ensino, nas Escolas Normais Rurais a que se refere o artigo anterior, obedecerá a legislação em vigor e as instruções que forem baixadas.

18 Por meio dos cursos normais regionais, de ciclo ginasial, uma formação simplificada foi instituída para os "regentes" das escolas primárias caracterizadas como de "caráter regional" (as localizadas nas zonas rurais, por exemplo) (PEREIRA, 2013, p. 103). Santa Catarina foi um dos Estados que se adaptou rapidamente à Lei Orgânica do Ensino Normal quando, ainda em dezembro de 1946, promulgou uma correlata lei estadual. Essa "agilidade" na resposta à normatização de nível nacional parece ter surtido efeitos, de modo que, em 1951, Santa Catarina era o primeiro Estado da federação na quantidade de cursos destinados a formar regentes do ensino primário, um total de trinta e oito (LOURENÇO FILHO, 1953 apud PEREIRA, 2013, p. 105). 
Art. $3^{\circ}$ - Fica assegurado aos professores formados por essas escolas Normais Rurais, as escolas primárias rurais serão regidas por professores diplomados por outras Escolas Normais do Estado.

(...). (SERGIPE, 1949 apud SILVA, 2016, p. 148).

Percebemos que na citada lei, os professores que fossem formados na Escola Normal Rural Murilo Braga, em Itabaiana e na Escola Normal Rural Sílvio Romero ${ }^{19}$, em Lagarto, deveriam ocupar os cargos do magistério primário nas escolas primarias rurais, pois de acordo com o governador José Rollemberg Leite e como já sinalizado, a escola primária rural no estado de Sergipe padecia com a falta de professores qualificados para atuarem em consonância com os princípios ruralistas. Foi então que, nesse contexto, Acrísio Cruz, Diretor do Departamento de Educação no governo estadual de Rollemberg Leite (19481951), recebeu apoio da União para que pudesse construir escolas rurais de ensino primário, assim como escolas normais rurais.

E assim foram criadas legalmente duas escolas normais rurais: uma em Itabaiana e a outra em Lagarto. A Escola Normal Rural Murilo Braga, situada em Itabaiana, foi criada em 29 de novembro de 1949 e oferecia o curso Ginasial e Pedagógico para os estudantes de Itabaiana e dos municípios circunvizinhos e "[...] deveria formar professores, sobretudo na zona rural da região, em um momento que apenas o Instituto de Educação Rui Barbosa cumpria esta missão" (BERGER, 2011). A respeito do funcionamento da escola normal rural de Lagarto, porém, não se tem encontrado informações na historiografia da educação sergipana e nas fontes documentais consultadas.

Com relação à formação na Escola Normal Rural, Berger (2011, p. 171) assim esclarece:

\begin{abstract}
A proposta curricular contemplava matérias ensejando ao professor o domínio dos conhecimentos das ciências e das técnicas pedagógicas; dos conhecimentos da escola primária; das técnicas de relações públicas e de comunicação com o homem simples; dos diversos padrões culturais do nosso rurícola; dos interesses dominantes e outros problemas que afetam o meio rural. Veiculava também conhecimentos de Economia e Sociologia rural para melhor compreensão da realidade e desenvolvimento do trabalho pedagógico.
\end{abstract}

Já no final da década de 1950, ao refletir sobre esse aspecto em Sergipe, Nunes Mendonça considerava que os cursos para formação de professores deveriam considerar eminentemente as características próprias do meio rural, e propunha que: "No curso, realizado em regime de comunidade de vida e de trabalho, com auto-disciplina, estudo dirigido, trabalhos em equipe, práticas agrícolas, etc., além dos estudos sistemáticos, cuidar-se-ia

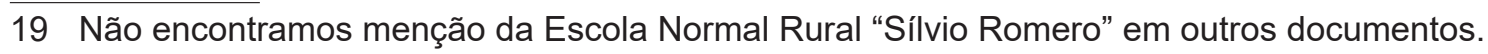


de desenvolver a aprendizagem de indústrias domésticas e rurais" (MENDONÇA, 1958, p. 177). E apontava que "[...] a formação do professor capaz de atuar eficazmente no meio rural, é um dos problemas educacionais que precisava de ser enfrentado, com ânimo e lucidez" (MENDONÇA, 1958, p. 177).

Mendonça (1958) ainda acentuou que o problema da atuação professoral no campo, bem como o déficit de professores no Estado de Sergipe era decorrente da resistência dos profissionais diplomados, o que contribuiu para que pessoas sem a formação adequada atuassem enquanto professores. Essa resistência era devido aos baixos salários que não estimulavam que os professores diplomados se deslocassem para o campo. E para suprir as vagas de professores nas zonas rurais era prática comum recrutar pessoas da própria comunidade, sem nenhum tipo de formação para atuar como professor.

Deste modo, muitas escolas do interior do Estado de Sergipe permaneciam fechadas por falta de professores que se habilitassem a ensinar nestes lugarejos onde não havia rodovias, eletricidade e outros confortos ligados à modernidade, além disso, os salários eram tão baixos que desestimulavam os profissionais habilitados. Assim, foram aproveitadas jovens dos municípios, que sabiam ler, escrever e contar, com o objetivo de preencher as vagas ociosas (REZENDE, 2014, p.132).

Essa questão e seus desdobramentos em termos qualitativos também foram abordados por Mendonça (1958). Para ele:

Segundo dados (sujeitos a retificação) colhidos no Serviço de Estatística Educacional militam em Sergipe no ensino público e particular, presentemente, apenas 470 professores diplomados. O número de leigos atinge a cifra de 970 professores, ou seja, em termos percentuais, $67,3 \%$, o que representa índice bem alto de improvisão, e assume caráter de gravidade, pois esse professorado leigo, na sua maioria, é composto de incapazes, semi-analfabetos e desinteressados, que vêm no magistério somente o ganha-pão. (MENDONÇA, 1958, p. 158).

Para minimizar essa problemática, propuseram cursos de formação para os professores já atuantes muitos com condições mínimas de formação. E assim a formação passou a acontecer por meio da oferta de cursos de curta duração, ocorridos geralmente no período de férias escolares e realizados na capital do Estado ou em outra cidade para onde os professores se deslocavam e permaneciam durante a sua realização. Segundo Rezende como forma de recrutamento (2014) a Secretaria da Educação e Cultura do Estado de Sergipe com o objetivo de viabilizá-los a fim de qualificar o corpo docente não titulado, enviava convite, via correio, para os professores se inscreverem.

Neste documento, o governo apresentava os cursos, os benefícios de quem aderisse e a situação de quem optasse por permanecer sem formação. As professoras que se interessavam preenchiam o formulário, faziam o curso e aguardavam o 
melhoramento salarial, através da elevação de nível. Aquelas que não optassem pelo treinamento e/ou aperfeiçoamento permaneceriam ganhando a mesma quantia. (...). Deste modo, as professoras "leigas" conseguiam concluir o ensino primário, secundário e finalmente realizar, via supletivo, o curso de magistério (REZENDE, 2014, p. 134).

Um ponto que merece destaque diz respeito às dificuldades para encontrar professores ou pessoas disponíveis para participarem desses cursos. De acordo com Rezende (2014, p. 137) "[...] a falta de transporte e os baixos salários podem ter sido fatores impeditivos para a não assistência". Além disso, a não participação no curso, por parte dos professores e professoras, não impedia as nomeações para assumirem as cadeiras criadas, pois com ou sem curso eles ensinavam o que sabiam, tendo em vista que as decisões para ingresso ou permanência no magistério ficavam a cargo da política partidária local.

Sobre tal prática e seus desdobramentos no sertão sergipano, Rezende baseando-se em Leite (1950) apresenta:

Vale ressaltar que o curso intensivo de educação rural surgiu no ano de 1949, as alunas permaneciam 56 dias na Escola Agrícola Quissamã e eram ministradas aulas de: "Agronomia Geral e Especial -Zootécnica Geral e Especial - Horticultura Geral e Especial-Avicultura Pomicultura - Combate às doenças e pragas das plantas cultivadas -Tecnologia - Jardinocultura - Palestras sobre organização e finalidades dos Clubes Agrícolas" (REZENDE, 2014, p.139).

A Recomendação $n^{\circ} 8$ da Unesco advogava ainda que o trabalho da escola rural deveria ser complementado ou facilitado por atividades extracurriculares, por meio da criação de clubes de jovens agricultores, institutos rurais para mulheres, bibliotecas itinerantes, filmes educacionais, missões educativas e culturais entre outros. O inciso 15 é taxativo:

15) O trabalho da escola rural deverá ser complementado ou facilitado por atividades extracurriculares ou pós-escolares, tais como clubes de jovens agricultores, institutos rurais de mulheres, transmissões rurais de bibliotecas itinerantes, filmes educativos, missões educacionais e culturais, cursos por correspondência. etc. (UNESCO, 1979, p. 19, tradução nossa).

Em Sergipe, em relação a esse aspecto, o técnico agrícola José Ribeiro Filho que trabalhou no Departamento de Educação de Sergipe (1948-1951), e foi responsável pela implantação do Serviço de Educação Rural (SER), afirmou que dentro do projeto de implantação da educação rural, além da formação de professores, eram realizadas atividades extracurriculares como reuniões nas escolas, convocação de pais dos alunos para assistirem palestras temáticas, além de distribuição de panfletos, mudas e sementes para os participantes. (BARRETO, 2006). Vale ressaltar que essas últimas práticas já estavam em uso no Brasil desde os anos de 1940, quando o Ministério da Agricultura programou ações de 
educação agrícola através das Semanas Ruralistas e que, por sua aceitação, foi também incorporada pelo ministério da educação.

Como preconizado outra atividade relacionada a essa perspectiva foi a criação dos clubes agrícolas ${ }^{20}$ que também foram implantados em algumas escolas rurais de Sergipe com o intuito de permitir, aos estudantes, a convivência coletiva em prol de melhoramento da comunidade rural. (BARRETO, 2006). A esse respeito, foram localizados e analisados Boletins de Inscrição de Clubes Agrícolas das escolas rurais de Sergipe ${ }^{21}$ afim de entender seu funcionamento e atuação. Esses Boletins contem informações como endereço, data de fundação, número de sócios, composição da diretoria e outros itens que retratam a existência ou não de condições para que seus membros pudessem atuar na escola rural, como por exemplo: elementos de trabalho (terreno, horta e jardim), criações (aves, abelha, bichos de seda, coelho), ferramentas, dinheiro, museu, biblioteca e proteção.

A partir da sua análise, pudemos perceber que essa era uma atividade extracurricular que visava integrar a comunidade ao ambiente escolar. Eram espaços criados para que a escola pudesse proporcionar aos rurícolas informações e comportamentos mais adequados à vida no campo, a fim de tanto melhorar as relações com a comunidade, quanto lhes proporcionar melhorias no trato com a terra, aumento da produção agrícola e o conhecimento de novas técnicas de plantio e colheita, assim como de ferramentas e maquinários modernos. (SERGIPE, 1950).

De acordo com documento intitulado "Relação de escolas rurais e da capital com Clubes Agrícolas em Funcionamento em Sergipe" foi possível identificar que em 1948 existiam 23 (vinte e três) Clubes Agrícolas instalados em escolas primárias rurais, em 1949 criaram-se mais 36 (trinta e seis) e em 1950 mais 17 (dezessete), totalizando 76 (setenta e seis). Nos grupos Escolares Rurais foram identificados 05 (cinco) Clubes Agrícolas e nos Grupos Escolares da Capital identificamos 06 (seis) e mais 01 (um) em um Jardim de Infância também na capital. (SERGIPE, 1950). Nesse aspecto, é interessante perceber a intenção do governo em atender mais essa recomendação da UNESCO, porém faz-se necessário a realização de estudos específicos a esse respeito, buscando fontes que possam esclarecer como esses Clubes Agrícolas funcionaram e que tipo de benefícios efetivamente trouxeram para os sergipanos naquele contexto.

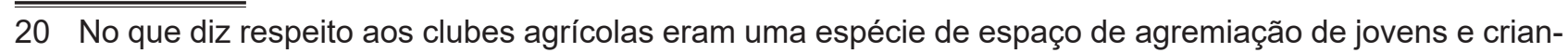
ças com o objetivo de difundir aos seus associados as primeiras noções de vida coletiva no meio rural, numa perspectiva de 'ruralismo infantil'. (MENDONÇA, 2010).

21 Esses Boletins foram encontrados no Arquivo Público Estadual de Sergipe junto a outros documentos da educação sergipana, porém não foram encontrados outros documentos informando como eles funcionaram nas escolas. 
No que tange a "Recomendação n²9", de 1950, esta trata do "Intercâmbio Internacional de Professores" e defende que esta era uma das maneiras mais eficazes e práticas de promover o entendimento entre povos de diferentes nacionalidades e culturas e de criar novos padrões educacionais. Nesse sentido, seria necessário associar os governos para promoção de programas que previssem o intercâmbio de educadores entre países. Nesse sentido indicava:

1) Uma ampla publicidade deverá ser realizada, entre instituições governamentais ou privadas e organizações profissionais no que concerne a educação e a promoção do acordo internacional, para programas com nomeações não permanentes e o intercâmbio de professores (UNESCO, 1979, p. 77, tradução nossa).

Assim, a experiência mais expressiva de intercâmbio de educadores foi a vinda, para o Brasil, do educador americano Robert King Hall ${ }^{22}$. Por meio de uma série de viagens King Hall estudou e colaborou com a educação do Brasil, inclusive ofertando curso de formação para professores primários rurais no Rio de Janeiro e em Sergipe, bem como preparando e publicando o fruto de seus diagnósticos e experiências. Contudo, não foi possível encontrar evidências ou mesmo indícios de educador/es sergipano/s que tenha/m ido fazer cursos nos Estados Unidos, todavia é notório na historiografia educacional brasileira que Anísio Teixeira, Lourenço Filho e outros educadores tenham ido participar de cursos nas universidades norte-americanas naquele contexto.

Ao longo das décadas de 1940 e 1950, Hall recebeu diversas bolsas de estudo concedidas por instituições norte-americanas e brasileiras para viajar pelo Brasil, realizando pesquisas sobre a situação educacional, chegando inclusive, a ser convidado pelo Instituto Nacional de Estudos Pedagógicos (Inep), para trabalhar, em regime de colaboração, num projeto de criação de escolas rurais (CUNHA, 2015, p. 14).

Nessa perspectiva, o educador americano atuou junto ao INEP prestando assessoria educacional e fomentando os ideais de desenvolvimento e de educação norte-a-

22 O professor norte-americano Robert King Hall foi um professor da Columbia University. Especialista em Educação Comparada, trabalhou no pós-Segunda Guerra, em missões culturais, financiado pelo governo norte-americano, com o objetivo de estudar os sistemas educacionais de diversos países, na Ásia e América do Sul. Os frutos das missões das quais participou podem ser comprovados pelas diversas publicações espalhadas pelo mundo a exemplo das obras: HALL, Robert King; STANTON, Margaret Gwenllian. Combate ao analfabetismo nas repúblicas a. b. c. Formação: Revista Brasileira de Educação, Rio de Janeiro v. 4, n. 36, p. 18 - 29, jul. 1941. Neste texto Hall apresenta uma análise do analfabetismo na Argentina, no Brasil e no Chile nas décadas de 1920 a 1940 apontando as ações governamentais desses países para o seu combate. Outras publicações de destaque resultantes de suas missões foram: HALL, Robert King. Japan. In: The yere Book Off Education 1950. London: 1949-1964 e HALL, Robert King. The Inep rural school programme of Brazil. In: The yere Book Off Education 1954. London: 1949-1964. 
mericanos e colaborou com o Ministério da Educação e Saúde/INEP, em 1946, quando da elaboração do projeto de criação e expansão das escolas rurais. Uma das ações que mais se destacou foi o curso para professores rurais que ele ministrou em 1949, no Rio de Janeiro durante o Seminário de Educação Rural, do qual participaram professores de diferentes estados do Brasil.

Diante da repercussão positiva do curso ofertado no Rio de Janeiro, King Hall pôde expandir sua atuação, pois foi convidado para ministrar o mesmo curso para professores rurais de Sergipe quando da sua visita ao estado. De acordo com Siqueira e Barreto (2017), naquele contexto Sergipe apesentava o maior número de escolas rurais em construção e este fato fez o diretor do INEP, Murilo Braga, convidá-lo a ministrar o referido curso em Sergipe, tendo em vista a necessidade de preparar os professores para atuarem nas novas escolas rurais, já que a maioria não possuía formação, era considerada leiga. De fato, para incluir nos currículos escolares do ensino primário as atividades relacionadas ao meio rural, como produção de hortas, o trato com sementes e mudas, assim como o trabalho nas granjas, era de fundamental importância a preparação desses professores com os conhecimentos mínimos para executarem a proposta pedagógica das escolas típicas rurais.

O curso ministrado por King Hall ocorreu no Instituto de Educação Rui Barbosa em Aracaju, em 1950 e contou com a participação de 55 professoras da área rural. Em Mensagem, o Governador José Rollemberg Leite (SERGIPE, 1951) destacou que o mesmo teve duração de 08 dias e também participaram educadores e políticos da capital e do interior. Entre os temas abordados durante sua realização, sobressaíram-se:

I- Integração da Escola Primária na Comunidade Rural. II- Elaboração do Programa para Escola Primária na Comunidade Rural. III- Formação de Professores para a Escola Rural. IV- O Professor da Escola Primária Rural e os nossos processos de desenvolvimento econômico. (SERGIPE, 1951, p. 75).

Cunha (2015, p. 17), por sua vez, atenta para o proposito do curso no tocante a formação especifica do professor. Segundo ela "O objetivo do curso era apresentar aos alunos palestras sobre as modernas técnicas de ensino que estavam sendo aplicadas na educação rural". Ainda segundo ela o curso se mostrava inovador, uma vez que adotou um método interativo utilizando-se da participação dos alunos nos debates dos temas, que giravam em torno da educação rural e suas implicações sociais, culturais, técnicas e educacionais.

No que se refere à "Recomendação n 36", de 1953, ela recai sobre a "Formação de Professores Primários" e considera que todas as crianças em todo o mundo têm o direito de serem educadas por professores primários que tenham uma boa formação e treinamento profissional. Assim, defende que nenhuma pessoa deveria ser nomeada para ensinar, mes- 
mo que temporariamente, a menos que ela possuísse qualificação profissional reconhecida. Outro entendimento presente nesta Recomendação é que a evolução e extensão da educação escolar exigem a contínua formação de professores primários e sua adaptação periódica às novas circunstâncias e necessidades emergentes. Assim, aconselhava a criação de um órgão especializado, fosse uma direção, departamento ou serviço responsável pela coordenação de todas as questões administrativas, financeiras e técnicas relativas à formação.

Nesse sentido, havia uma preocupação não só com a formação do professor, mas com a necessidade de criar uma estrutura administrativa que pudesse organizar esse processo, como podemos ver a seguir.

1) A evolução e a extensão da educação escolar exigem o estudo contínuo da formação inicial de professores e sua adaptação periódica às circunstâncias e necessidades emergentes;

2) Tendo em vista a crescente complexidade dos problemas de formação de professores, é aconselhável ter um órgão especializado (diretoria, departamento ou serviço) responsável pela coordenação de todas as questões administrativas, financeiras e técnicas relativas a esse treinamento (UNESCO, 1979, p.111, tradução nossa).

Sob tal recomendação, em Sergipe foi criado, no Departamento de Educação do Estado, o Serviço de Educação Rural (SER) que teve como objetivo ofertar os já referidos cursos para professores rurais, auxiliar as escolas na aquisição de utensílios agrícolas, fornecer orientações para a realização de atividades agrícolas nas escolas, a exemplo de hortas e melhoria no trato com a terra e com a criação de animais, assim como despertar os professores para os motivos rurais. Sobre essa questão, José Ribeiro Filho apresentou, em relatório manuscrito ${ }^{23}$, como foi desenvolvido um curso para professores rurais ofertado pelo SER que:

Organizou e fez em prática um curso de Agricultura com 2 finalidades principais: 1) Dá conhecimento de práticas agrícolas modernas; 2) Incutir-lhe numa mentalidade rural por meio de palestras, cinema, literatura. [...] Foram ministrados conhecimentos sobre: Hortalicicultura, Agronomia, Indústrias Rurais e Jardinocultura. (SERGI$\mathrm{PE}, 1948)$.

Segundo o professor José Ribeiro Filho, dentre as ações desse serviço estava a de colaborar com as escolas rurais no sentido de prepará-las para desenvolver atividades de agricultura como plantação de hortaliças e criação de granjas para produção de aves e de outros animais, bem como era fundamental a oferta de cursos para os professores rurais

23 Documento manuscrito localizado na pacotilha no 148 - E2 no acervo do Arquivo Público Estadual de Sergipe. 
adquirirem tais conhecimentos, tanto teórico quanto práticos (RIBEIRO FILHO, 2006 apud BARRETO, 2006).

Assim o "Curso de Agricultura" ministrado pelo professor José Ribeiro Filho, em 1948 foi realizado por meio de aulas teóricas que ocorreram na sede da Escola Normal "Rui Barbosa" localizada em Aracaju, e de aulas práticas realizadas no Aviário D. Pedro II, localizado no povoado Sobrado, na capital. No aviário ficava o galinheiro e uma grande área onde estavam plantadas as hortas. Para se deslocarem ao aviário, os alunos e o professor pegavam uma marinete. Segundo um manuscrito do professor Ribeiro, participaram desse curso mais de 100 professores distribuídos em turmas diferentes com denominações das letras do alfabeto (turma A, turma B...) (SERGIPE, 1948).

Por fim, a "Recomendação n 47" de 1958 que orienta como devem ser as "Instalações para Educação em Áreas Rurais". A UNESCO partia do pressuposto de que grande parte da população rural do mundo vivia na ignorância e que este fato causava um desequilíbrio e inevitavelmente retardava o progresso das nações. Indicou que a desigualdade de oportunidades educacionais de muitas crianças constituiam uma injustiça que exigia urgentemente uma solução. Outro fato que chama à atenção é que a escola rural, como também a escola urbana, deveria ser um centro de cultura e de progresso social e econômico para toda a comunidade, porém em alguns locais, as escolas rurais apresentavam problemas extremos de estrutura e de funcionamento, o que impedia o progresso intelectual e profissional dos alunos.

A Recomendação $n^{\circ} 47$ definia ainda como governantes deveriam organizar a educação nas áreas rurais, destacando a necessidade da criação de cursos de formação de professsores, organização curricular, prédios escolares apropriados e inventários da situação educacional do lugar. Foram determinações:

1) As autoridades responsáveis pela administração escolar devem organizar para todas as crianças em áreas rurais educação do mesmo padrão que as fornecidas para crianças em áreas urbanas. Para o efeito, os seus deveres devem incluir, em especial:

a) elaborar um inventário dos requisitos educacionais das áreas rurais;

b) determinar a natureza particular da organização educacional, currículos e métodos a serem adotados nas áreas rurais;

c) lançamento de planos de ação (cursos, edifícios escolares, corpo docente, equipamentos, serviços sociais escolares, etc.). [...] (UNESCO, 1979, p.192, tradução nossa).

Nesse aspecto, Acrísio Cruz participou da construção de mais de 200 (duzentas) escolas rurais utilizando o modelo arquitetado pelo INEP, qual seja, "[...] a Escola Rural, 
por exemplo, juntava sala de aula multisseriada, com a moradia da professora, em dois cômodos principais, enriquecidos com uma área entre eles, que servia para a recreação" (BARRETO, 2006, p. 16). Esse modelo de escola permitia que os alunos entrassem em contato com a terra por meio da realização de atividades agrícolas, como o plantio de hortaliças e a criação de animais, colocava também as crianças em contato com a família do/a professor/a, já que morando na "própria escola" era possível que este/esta tivesse um contato mais próximo com os alunos e desenvolvesse neles hábitos pertinentes à sociedade moderna. (BARRETO, 2006).

Uma das primeiras iniciativas sobre os cursos de treinamento e aperfeiçoamento para professores rurais a partir de iniciativas do governo federal (INEP) em parceria com o governo estadual, foram os Cursos Intensivos de Educação Rural. A partir de 1948, foi instituído, como relata a mensagem do governador José Rollemberg Leite:

[...] um Curso intensivo de Educação Rural, com uma matrícula de cêrca de 140 professoras, sob a direção de um técnico agrícola, desenvolvendo um programa bastante prático, que corresponde ao que foi planejado por aquele Departamento. De fato, maior despesa se tem a fazer. A aquisição de material didático especial para aquele ramo de ensino não se fez sem o dispêndio de, pelo menos, dois mil cruzeiros por escola. (SERGIPE, 1948, p. 13).

Nesse cenário composto por escolas rurais e professores em formação, os preceitos ruralistas que consistiam entre outras coisas em equipar as escolas com materiais para o meio rural, foram adotados através da aquisição de enxadas, baldes, arado, sementes, para além da necessidade de que os professores fossem preparados para desempenhar seu papel frente às comunidades rurais. $E$ assim, segundo o governador José Rollemberg Leite: "À medida que foi possível, deu-se a organização típica rural de muitas escolas, [...] que foram aparelhadas de instrumental agrícola além de manter-se um trabalho intenso de preparo do professorado que se habilitou à tarefa docente rural" (BRASIL/SERGIPE, 1949, p. XIV).

Assim, já em em 1948, precisamente de 03 de fevereiro a 13 de março, no período de férias escolares, foi realizado em Sergipe o Curso de Educação Rural ministrado pelo professor José Ribeiro Filho. Foram inscritos 72 (setenta e dois) professores. O curso ofertou as seguintes disciplinas: Agronomia Geral e Especial, Zootecnia Geral e Especial, Horticultura Geral e Especial, Pomicultura, Combate às doenças e pragas das plantas cultivadas, Tecnologia e Jardinocultura. Foram realizadas também Palestras sobre Organização e Finalidades dos Clubes Agrícolas. (SERGIPE, 1948).

No ano seguinte, foi realizado outro curso para professores rurais, chamado Curso de Formação de Professores Rurais. Segundo o Relatório do Diretor Geral do Departamento de 
Educação, Acrísio Cruz e do Inspetor Geral do Ensino Normal e Primário, Exupero Monteiro (Sergipe, 1950) o curso aconteceu de 04 a 31 de janeiro de 1950 (primeira parte) e de 01 de fevereiro a 07 de março de 1950 (segunda parte), também realizado no período de férias escolares. O currículo desse curso foi extenso e contou com a participação dos professores: Acrísio Cruz que ministrou a disciplina Administração Escolar e Instituições Complementares da Escola; o professor José Ribeiro Filho, a disciplina Prática de Pomicultura e Horticultura e Noções de Agricultura, Criação de Animais Domésticos; o professor José Menezes de Oliveira, a disciplina Criação de Animais Domésticos e Apicultura; a professora Elze Silva Dantas, a disciplina Indústrias Rurais Caseiras; o professor Dr. Emanuel Franco, a disciplina Indústrias Rurais Caseiras; o professor Dr. Júlio de Oliveira, a disciplina Noções de Veterinária; e o professor Dr. Aloísio Coutinho ministrou a disciplina Noções de Higiene Rural. Esse curso contou com 55 (cinquenta e cinco) professores inscritos. (SERGIPE, 1950).

A Recomendação $n^{\circ} 47$ também defendia que os currículos das escolas rurais deveriam se inspirar na vida e no trabalho do campo, contribuindo para o desenvolvimento de uma prática que melhorasse a vida na comunidade rural. Nesse sentido, os objetivos da escola primária rural deveriam ir além de ensinar a ler, escrever e contar, devendo incluir em sua proposta pedagógica atividades voltadas para o trabalho agrícola. A partir dessa prerrogativa em Sergipe passou a ser defendido que "[...] as escolas rurais deveriam ministrar cursos de horticultura, jardinagem, avicultura, apicultura e várias atividades, sem prejuízo do curso primário propriamente" (SILVA, 2016, 106-107).

Com tais Recomendações a UNESCO pode interferir diretamente na elaboração e execução de projetos e ações voltadas para expansão e modernização da educação rural no mundo. No que se refere ao Brasil, mas especificamente a à Sergipe pudemos verificar que diversas mudanças foram implementadas no tocante à organização e estrutura física e curricular das escolas rurais, assim como foram realizados cursos de formação para os professores com o objetivo de que eles pudessem atuar na perspectiva de atender as propostas governamentais inspiradas nas referidas Recomendações. Estas defendiam uma atuação governamental que considerasse os aspectos racionais e científicos na administração e especificamente o campo educacional. À escola rural foi atribuída não somente a função de alfabetizar, mas também a de criar meios para favorecer as crianças e às suas famílias, sobretudo no que tange a aquisição da dignidade da vida no campo e da melhoraria das condições de trabalho e de produção no meio rural.

\section{CONSIDERAÇÕES FINAIS}

Como foi apresentado, a UNESCO constituiu-se enquanto órgão ligado à ONU e, sob orientação dos Estados Unidos, pactuou junto com outros organismos internacio- 
nais a promoção de ações de desenvolvimento em todas as nações. Para tanto, atuou incisivamente junto a diversos países do mundo, inclusive o Brasil, por meio de acordos de cooperação técnica no campo da educação, visando tanto sua expansão, quanto a modernização.

Nesse sentido, a partir das Conferências Internacionais de Educação, verificamos que a UNESCO estabeleceu 71 (setenta e uma) Recomendações no período de 1934 a 1977, das quais destacamos, neste estudo, a nº 8 que se refere à organização da educação rural (1934), a n 29 que retrata o intercâmbio internacional de professores (1950), a n 29 que incentiva a formação de professores primários (1953) e a $n^{\circ} 47$ que aborda sobre as instalações para educação em éreas rurais (1958). Essas Recomendações nortearam as mudanças na política educativa, refletindo diretamente na educação rural em Sergipe nas décadas de 1940 e 1960, quando foram implantadas diversas ações nessa área, como por exemplo a criação de escolas típicas rurais, escola normal rural e cursos de férias para formação de professores rurais.

O resultado que ficou evidenciado foi a supremacia norte-americana, sobretudo no que se refere às politicas de promoção do campo. Do ponto de vista econômico, há que se considerar que houve um freio considerável no êxodo rural e que o campo, a partir de então, contou com estratégias de potencialização. Já com relação à educação não se pode negar a formação aligeirada dos professores e a pouca eficácia desta formação, haja vista que, embora os relatórios dos cursistas destaquem a formação agrícola recebida, os ali preparados não foram à prática, mas isso é outro capítulo dessa história...

\section{REFERÊNCIAS}

ÁVILA, Virgínia Pereira da Silva de. História do ensino primário rural em São Paulo e Santa Catarina (1921 - 1952): uma abordagem comparada. 215f. Tese (Doutorado em Educação Escolar) - Faculdade de Ciências e Letras, Universidade Estadual Paulista “Júlio de Mesquita Filho", Araraquara, 2013.

BARRETO, Luiz Antônio. Antologia Acrísio Cruz. Edição Comemorativa do Centenário de Nascimento de Acrísio Cruz. Secretaria de Estado da Cultura. Aracaju: 2006.

BERGER, Miguel André. O ensino rural e a atuação do intelectual Acrísio Cruz. Revista da FAEEBA - Educação e Contemporaneidade. Salvador, n. 36, p. 165-173, jul./dez. 2011. 
CARVALHO, Marcus Vinícus Corrêa. Moderno, Modernidade, Modernização: Polissemias e Pregnâncias. In: GIL, Natália; ZICA, Matheus da Cruz; FARIA FILHO, Luciano Mendes de (Orgs.). Moderno, Modernidade, Modernização: a educação nos projetos de Brasis séculos XIX e XX (vol. 2). Belo Horizonte: Mazza Edições, 2012.

CUNHA, Adriana Mendonça. Notas iniciais sobre Robert King Hall e as missões culturais norte-americanas no Brasil (1940-1950). Boletim Historiar, n.10, jul./ago. 2015, p.13-19.

DANIEL, Leziany Silveira. João Roberto Moreira (1912-1967): Itinerários para uma Racionalidade Ativa. Tese (Doutorado) - Programa de Pós-Graduação em Educação, Universidade Federal do Paraná, 2009.

DAROS, Maria das Dores. Desenvolvimentismo e Políticas educativas no Brasil nos anos 1950-1960: transnacionalização e modernização. In: GIL, Natália; CRUZ e ZICA, Matheus; FILHO, Luciano Mendes Faria. In: Moderno, modernidade e modernização: a educação nos projetos de Brasil - séculos XIX e XX. Belo Horizonte: Mazza Edições, 2012.

EVANGELISTA, Ely Guimarães dos Santos. A UNESCO e o mundo da cultura. Campinas, SP: Edições UNESCO Brasil, 1999.

LOMBARDI, José Claudinei. Educação e Nacional-Desenvolvimentismo (1946-1964). Revista HISTEDBR On-line, Campinas, n. 56, p. 26-45, maio 2014.

MENDONÇA, Sônia Regina. Estado, educação rural e influência norte-americana no Brasil (1993-1961). Niterói: Ed. UFF, 2010.

MENDONÇA, José Antônio Nunes. A Educação em Sergipe. Aracaju: Livraria Regina Ltda., 1958.

NUNES MENDONÇA, José Antonio. A Educação em Sergipe. Aracaju: Livraria Regina Ltda., 1958.

PEREIRA, Elaine Aparecida Teixeira. Modernizar o Arcaico: Discursos sobre a formação de professores para o meio rural (Santa Catarina 1942-1959). Dissertação apresentada ao Programa de Pós-Graduação em Educação da Universidade Federal de Santa Catarina, sob orientação da Professora Dra Maria das Dores Daros, 2013.

REZENDE, Cacia Valeria de. Educação no sertão: memórias e experiências das professoras no alto sertão sergipano (1950 - 1970). 217f. Dissertação (Mestrado em Educação) - Universidade Tiradentes - Unit, Aracaju, 2014. 
ROMANELLI, O. História da Educação no Brasil:1930-1973. Petrópolis, Vozes, 1978.

SILVA, Rony Rei do Nascimento. Memórias caleidoscópicas: configurações das escolas rurais no estado de Sergipe (1947-1951). Dissertação (Mestrado). Programa de Pós-Graduação em Educação, Universidade Tiradentes, 2016.

SIQUEIRA, Maryluze Souza Santos; BARRETO, Raylane Andreza Dias Navarro. Formação de professores e o projeto de modernização do rural em Sergipe (1940-1950). In: DAROS, Maria das Dores; Pereira, Elaine A. Teixeira. (Org.). Sentidos da educação e projetos de Brasil - séculos XIX e XX. 1 ed, pp. 1-20. Belo Horizonte: Mazza Edições, 2017.

\section{FONTES DOCUMENTAIS}

BRASIL. Decreto-Lei n ${ }^{\circ}$ 8530, de 02 de jan. de 1946. Aprova a Lei Orgânica do Ensino Normal. Diário Oficial da União nº 03, 04 jan. 1946.

BRASIL/SERGIPE. Boletim de Inscrição de Clubes Agrícolas. Departamento de Educação. Serviço de Educação Rural. Serviço de Informação Agrícola do Ministério da Agricultura. 1949.

SERGIPE. Relatórios de Atividades de Aulas Práticas (alunos) do Curso de Agricultura para formação de professores rurais. Departamento de Educação. Serviço de Educação Rural, 1948.

SERGIPE. Clubes Agrícolas em Funcionamento nas Escolas Rurais e Grupos Escolares do Estado de Sergipe durante os anos de 1948,1949 e 1950. Departamento de Educação. Serviço de Educação Rural, 1950.

SERGIPE. Mensagem apresentada à Assembleia Legislativa Estadual por ocasião da abertura da sessão legislativa de 1951, pelo Dr. José Rollemberg Leite, governador do estado de Sergipe. Aracajú: Diretoria Geral Do Departamento de Educação. 1951.

SERGIPE. Relatório Manuscrito do professor José Ribeiro Filho. Departamento de Educação. Serviço de Educação Rural (1948).

SERGIPE. Mensagem apresentada à Assembleia Legislativa Estadual por ocasião da abertura da sessão legislativa de 1948, pelo Dr. José Rollemberg Leite, governador do estado de Sergipe. Aracajú: Diretoria Geral Do Departamento de Educação. 1948. 
SERGIPE. Mensagem apresentada à Assembleia Legislativa Estadual por ocasião da abertura da sessão legislativa de 1949, pelo Dr. José Rollemberg Leite, governador do estado de Sergipe. Aracajú: Diretoria Geral Do Departamento de Educação. 1949.

SERGIPE. Relatório do diretor geral Acrísio Cruz e Exupero Monteiro, Inspetor Geral do ensino normal e primário. Departamento de Educação. 1950.

UNESCO. Recommandations 1934-1977. Conference Internationale do l'Education. France: Imprimerie de la Manutention à Mayenne, 1979. 